\begin{tabular}{|l|l|}
\hline 2. To: (Receiving Organization) & 3. From: (Originating Organization) \\
Distribution & LWP System Engineering \\
\hline 5. Proj./Prog./Dept./Div.: & 6. Design Authority/ Design Agent/Cog. \\
$\begin{array}{l}\text { W-252/Liquid Waste } \\
\text { Processing }\end{array}$ & A.F. Crane \\
\hline
\end{tabular}

8. Originator Remarks:

The 284-E Powerhouse Trench Engineering Study provides the

basis for future use of the trench as a transport conduit for effluents discharged from the 284-E Powerhouse.

11. Receiver Renarks: 11A. Design Baseline Document? [] Yes [X] No

NA

4. Related EDT No.:

NA

7. Purchase Order Mo.:

NA

9. Equip./Component Ho.:

NA

10. System/Bldg./Facility: 283-E/284-E

12. Major Assm. Dwg. No.:

NA

13. Permit/Permit Application No.: ST 4502

14. Required Response Date: $01 / 14 / 96$

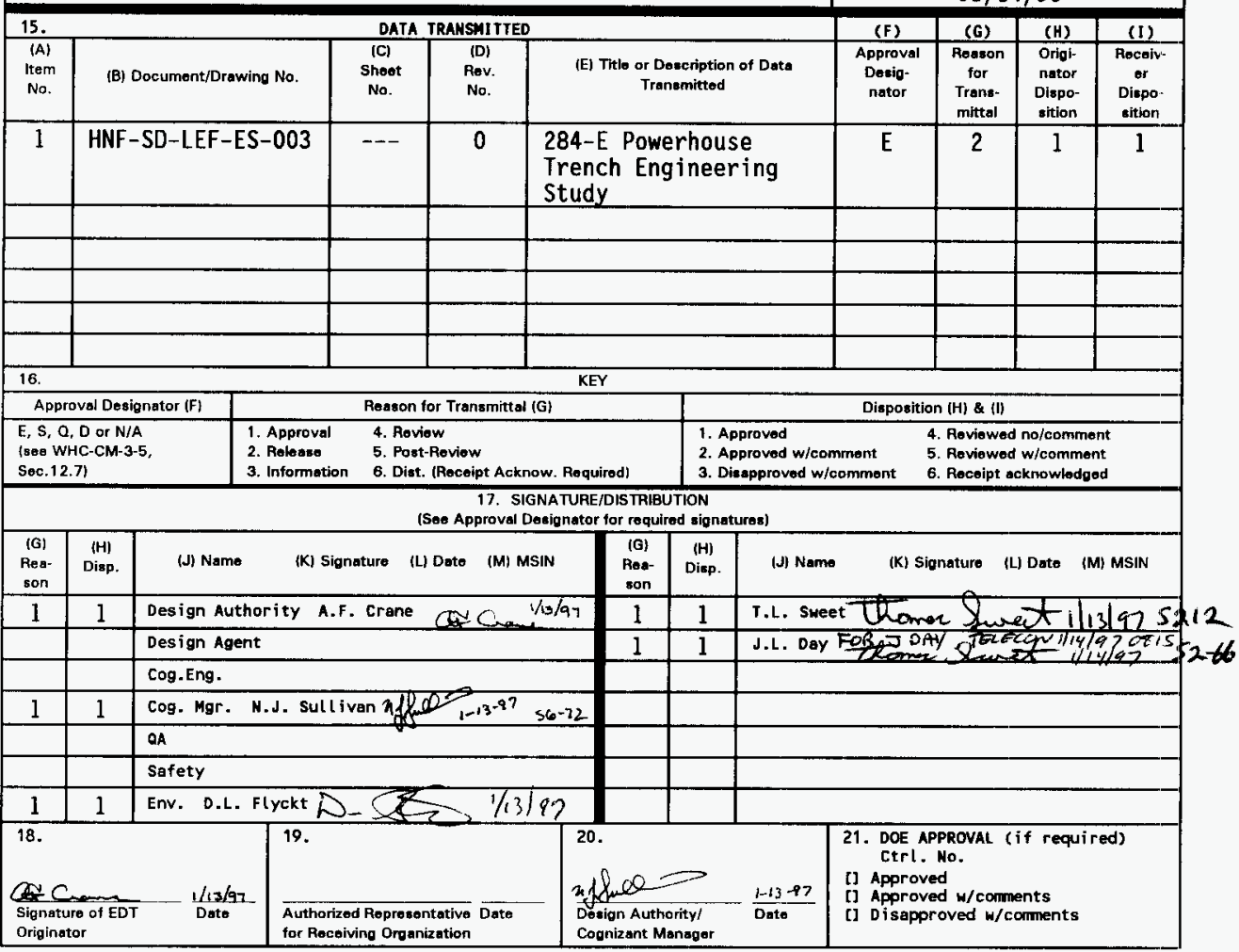




\title{
284-E Powerhouse Trench Engineering Study
}

\author{
A.F. Crane \\ Rust Federal Services of Hanford, Inc., Richland, WA 99352 \\ U.S. Department of Energy Contract DE-AC06-87RL10930
}
EDT/ECN: 611005
UC: 502
Org Code: 32200
Charge Code: A2187
B\&R Code: EW3130020
Tota1 Pages: 16

Key Words: 284-E, Powerhouse, Trench, 200 Area TEDF

Abstract: This document provides the basis for future use of the 284-E Powerhouse Trench as a transport conduit for effluents discharged from the 284-E Powerhouse in accordance with the requirements of the State Waste Discharge Permit, ST 4502.

TRADEMARK DISCLAIMER. Reference herein to any specific commercial product, process, or service by trade name, trademark, manufacturer, or otherwise, does not necessarily constitute or imply its endorsement, recommendation, or favoring by the United States Goverment or any agency thereof or its contractors or subcontractors.

Printed in the United States of America. To obtain copies of this document, contact: WHC/BCS Document Control Services, P.O. Box 1970, Mailstop H6-08, Richland wA 99352, Phone (509) 372-2420; Fax (509) 376-4989.
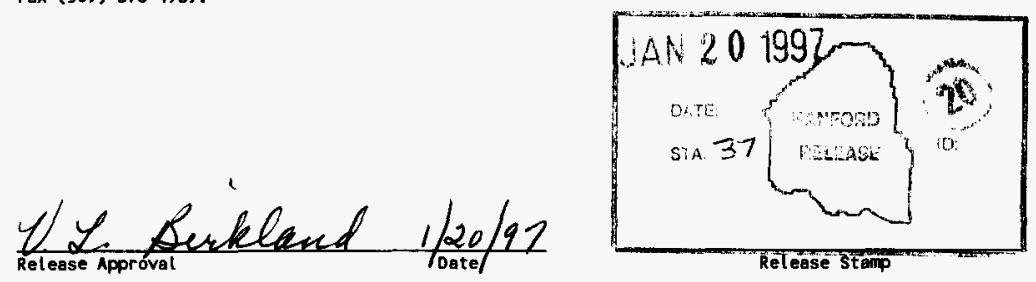

\section{Approved for Public Release}




\title{
284-E POWERHOUSE TRENCH ENGINEERING STUDY
}

\author{
HNF-SD-LEF-ES-003, Rev. 0
}

Prepared for:

Rust Federal Services of Hanford, Inc.

by

Los Alamos Technical Associates, Inc.

Richland, Washington

January 10, 1997 
HNF-SD-LEF-ES-003, Rev. 0

This page intentionally left blank. 


\section{CONTENTS}

1.0 INTRODUCTION $\ldots \ldots \ldots \ldots \ldots \ldots \ldots \ldots \ldots \ldots \ldots \ldots \ldots \ldots \ldots \ldots \ldots \ldots$

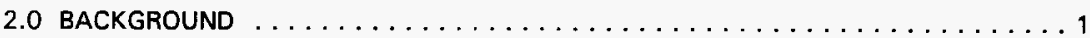

3.0 FACILITY DESCRIPTION AND CONFIGURATION $\ldots \ldots \ldots \ldots \ldots \ldots \ldots$

3.1 ORIGINAL SITE MAPS $\ldots \ldots \ldots \ldots \ldots \ldots \ldots \ldots \ldots \ldots \ldots \ldots \ldots \ldots$

3.2 REVISED SITE MAPS $\ldots \ldots \ldots \ldots \ldots \ldots \ldots \ldots \ldots \ldots \ldots \ldots$

3.3 CONSTRUCTION OF THE NEW CROSS SITE TRANSFER LINE $\ldots \ldots \ldots \ldots$

3.4 REPLACEMENT OF THE EAST END OF THE POWERHOUSE WASTEWATER TRENCH WITH PIPING $\ldots \ldots \ldots \ldots \ldots \ldots \ldots \ldots$

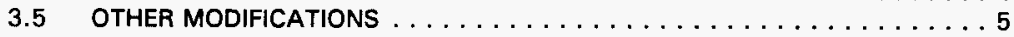

3.6 CURRENT WASTEWATER TRENCH CONFIGURATION AND OPERATION . . . 5

4.0 EFFECT OF TRENCH OPERATION ON HANFORD SITE GROUNDWATER $\ldots \ldots \ldots \ldots 5$

5.0 POWERHOUSE TRENCH MANAGEMENT OPTIONS $\ldots \ldots \ldots \ldots \ldots \ldots \ldots$

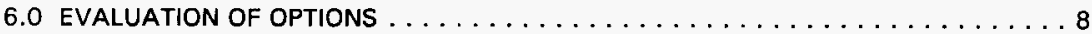

6.1 ACCEPTANCE AT TEDF $\ldots \ldots \ldots \ldots \ldots \ldots \ldots \ldots \ldots$

6.2 MOBILIZATION OF CONTAMINANTS FROM NEARBY FACILITIES $\ldots \ldots \ldots 8$

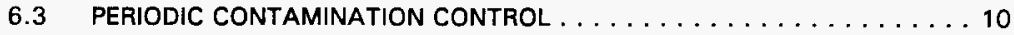

6.4 CAPITAL COSTS FOR CONSTRUCTION $\ldots \ldots \ldots \ldots \ldots \ldots \ldots \ldots \ldots$

7.0 CONCLUSIONS AND RECOMMENDATIONS $\ldots \ldots \ldots \ldots \ldots \ldots \ldots \ldots \ldots$

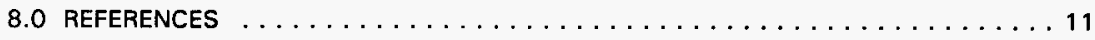

\section{LIST OF TABLES}

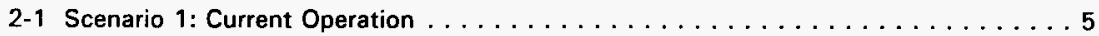

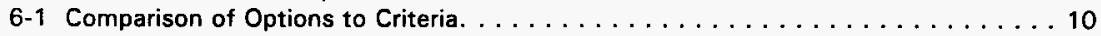

\section{LIST OF FIGURES}

3-1 Current Trench Configuration $\ldots \ldots \ldots \ldots \ldots \ldots \ldots \ldots \ldots \ldots \ldots \ldots \ldots \ldots \ldots$ 
This page intentionally left blank. 


\subsection{INTRODUCTION}

This engineering study evaluates use of the 284-E Powerhouse Trench as a transport conduit to the 200 Area Treated Effluent Disposal Facility (TEDF) and the acceptability of continued use as committed to in the 200 Area TEDF Supplemental Permit Application (DOE $1996 \mathrm{~b})$. Finally, this study recommends changes to the trench which may be necessary to meet either environmental or operational requirements.

\subsection{BACKGROUND}

The 284-E Powerhouse Trench receives effluent from the 200 East Area Powerhouse and Water Treatment Plant. Contributors to this waste stream are identified in Table 2-1. The trench, which has been in use for several decades, currently discharges to $B$ Pond. Project W-252 will reroute the discharge from B Pond to the 200 Area TEDF. The trench presently provides three functions, which are:

- Transport - the trench conveys the wastewater to a pipeline that discharges to B Pond.

- Surge capacity - the trench provides flow equalization to eliminate peak flows.

- Suspended solids removal - the trench provides suspended solids removal of alum (aluminum sulfate) sludges from the water treatment facility settling basins and multimedia filters.

Engineering Change Notice (ECN) No. 609363, March 27, 1995 (to WHC 1992), established BAT/AKART for the 284-E and 283-E facilities as current status while Engineering Change Notice No. 627698, February 14, 1996 (to WHC 1992) documented a decision to dispose of all Project W-252 Phase II streams, which includes this stream, to the 200 Area TEDF. These ECNs were submitted to the Washington Department of Ecology and approved in March of 1996 (DOE 1996b).

When the disposal point was changed to the TEDF, no decision was made as to the future use of the 284-E Powerhouse Trench. A Supplemental Permit Application for the 200 Area TEDF (DOE 1996b) was prepared in October 1996 to include the remaining Phase II streams and identified the need to evaluate the operation of the trench. This study is intended to provide the needed evaluation of the 284-E Powerhouse Trench and the acceptability of continued use of the trench from an engineering/environmental standpoint. 
Table 2-1. Current Operations.

\begin{tabular}{|c|c|c|c|c|c|}
\hline is. & 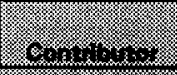 & 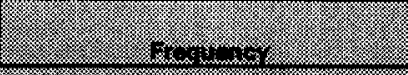 & 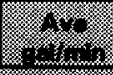 & 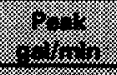 & 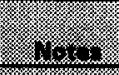 \\
\hline \multicolumn{6}{|c|}{ 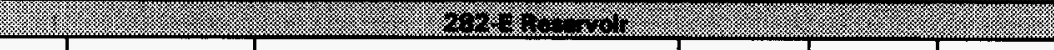 } \\
\hline 1 & Overflow & $\begin{array}{l}\text { Intermittent, with low probability } \\
\text { due to level controls }\end{array}$ & 0.8 & 7,000 & \\
\hline $1 \mathrm{~A}$ & $\begin{array}{l}\text { Pump House } \\
\text { floor, trench } \\
\text { drains }\end{array}$ & Intermittent & 1 & & \\
\hline $1 \mathrm{~B}$ & $\begin{array}{l}282-E C \\
\text { Pump House } \\
\text { floor, trench } \\
\text { drains, steam } \\
\text { condensate }\end{array}$ & $\begin{array}{l}\text { Intermittent, at completion of } \\
\text { Project B-604; } 4 / 97\end{array}$ & 0.7 & 6 & \\
\hline \multicolumn{6}{|c|}{ 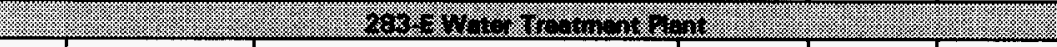 } \\
\hline 2 & $\begin{array}{l}\text { Filter } \\
\text { Backwash }\end{array}$ & $\begin{array}{l}\text { Intermittent, } 8 \mathrm{~min} \text { at } 4,000 \mathrm{gpm} \\
\text { plus } 4 \mathrm{~min} \text { rewash at } 200 \mathrm{gpm} \text {. } \\
7.5 \text { backwashes } / \mathrm{month} \text { for each } \\
\text { of } 4 \text { filters }\end{array}$ & 23 & 4,000 & $\begin{array}{l}\text { alum } \\
\text { sludge }\end{array}$ \\
\hline 6 & $\begin{array}{l}\text { Clearwell } \\
\text { Overflow } \\
\end{array}$ & $\begin{array}{l}\text { Low probability due to level } \\
\text { controls }\end{array}$ & $<0.02$ & 560 & \\
\hline $8 \mathrm{~A}$ & $\begin{array}{l}\text { Sample } \\
\text { sink/floor, } \\
\text { trench } \\
\end{array}$ & Continuous & 15 & & \\
\hline 7 & $\begin{array}{l}\text { Settling } \\
\text { Basin Drain }\end{array}$ & $\begin{array}{l}\text { Intermittent, } 2 \text { times/year (for } \\
\text { each of } 4 \text { basins) - } 200,000 \mathrm{gal} \\
\text { in } 6 \mathrm{hrs} \text { followed by } 2 \mathrm{hrs} \text { at } \\
100 \mathrm{gpm}\end{array}$ & $<0.02$ & 560 & $\begin{array}{l}\text { alum } \\
\text { sludge }\end{array}$ \\
\hline \multicolumn{6}{|c|}{ 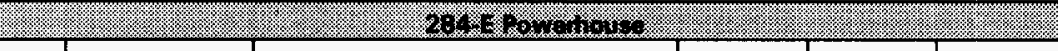 } \\
\hline 3 & $\begin{array}{l}\text { Cooling } \\
\text { Water }\end{array}$ & Continuous - 2 boilers on line & 75 & & \\
\hline 4A & $\begin{array}{l}\text { Continuous } \\
\text { Boiler } \\
\text { Blowdown } \\
\end{array}$ & $\begin{array}{l}\text { Continuous - steam load of } \\
65,000 \mathrm{lb} / \mathrm{hr}\end{array}$ & 24 & & \\
\hline 4B & $\begin{array}{l}\text { Batch Boiler } \\
\text { Blowdown }\end{array}$ & $\begin{array}{l}\text { Intermittent, active only on boiler } \\
\text { start up or shutdown. } 15-20 \\
\text { second burst flow over } 1 / 2 \text { hour }\end{array}$ & 2.3 & 100 & \\
\hline 5 & $\begin{array}{l}\text { Water } \\
\text { Softener }\end{array}$ & Intermittent, $180 \mathrm{~min}$ at $67 \mathrm{gpm}$ & 6.8 & 67 & $\begin{array}{l}\text { dissolved } \\
\text { solids, } \\
\mathrm{NaCl}\end{array}$ \\
\hline \multirow[t]{2}{*}{$8 \mathrm{~A}$} & $\begin{array}{l}\text { Floor/trench } \\
\text { drains }\end{array}$ & $5 \mathrm{~min}$ at $15 \mathrm{gpm}$ & $<0.02$ & 15 & \\
\hline & & TOTAL & 149 & & \\
\hline
\end{tabular}

References: DOE 1996b, ICF-KH 1996 


\subsection{FACILITY DESCRIPTION AND CONFIGURATION}

\subsection{ORIGINAL SITE MAPS}

The 284-E Powerhouse Trench is identified on Hanford Drawing M-2904-E, Sheet 24 (dated November, 1954) showing the trench to be $8 \mathrm{ft}$. wide at the bottom, with a 2.5:1 side slope, and a depth of 3 feet. The trench bottom slope is identified at $0.09 \%$ The entrance to the trench is from a 42 inch diameter pipe while the exit is through a 30 inch diameter pipe. The trench runs to the northeast for its first $100 \mathrm{ft}$., then proceeds due east for approximately $1800 \mathrm{ft}$., then runs northeast again for its last $375 \mathrm{ft}$. The original total length of the trench was approximately $2,275 \mathrm{ft}$. The following facilities and structures are located within approximately $500 \mathrm{ft}$. of the original trench:

- Railroad tracks leading to Purex - approximately $100 \mathrm{ft}$. south of the majority of the trench and approximately $50 \mathrm{ft}$. south of the trench entrance (drawing M-2904).

- North end of Purex sanitary sewer tile field - approximately $475 \mathrm{ft}$. south of the trench (drawings $\mathrm{M}-2904$ \& $\mathrm{H}-2-55537$ ).

- 216-A-9 Purex Crib - the nearest point is approximately $325 \mathrm{ft}$. southeast of the trench (drawing M-2904).

- 2-3 inch steel direct buried process sewer pipeline connecting 241-CR-131 and 241-CR vault with 241-A tank farm - approximately $212 \mathrm{ft}$. from the trench with the closest point being east of the trench discharge end (drawing M-2904).

- Encased process pipeline (drawing H-2-43044) - approximately $340 \mathrm{ft}$ north of the trench and running parallel for approximately $900 \mathrm{ft}$. (drawing $\mathrm{H}-2-43044$ ).

- C Plant (Hot Semiworks) facilities including process waste crib, organic crib, leaching pit, high salt crib, 241-CX farm, 216-C10 crib - closest distance approximately $388 \mathrm{ft}$. north of the trench (drawing M-2904).

\subsection{REVISED SITE MAPS}

A more recent set of Hanford Site Maps ( $\mathrm{H}-2-44500$ and 44501$)$ shows additional facilities in the vicinity of the trench. Sheet 71 of drawing $\mathrm{H}-2-44501$ shows the trench to have a 6-8 ft. wide bottom and refers to drawing $\mathrm{H}-2-55548$. In addition, a portion of the trench (about $100 \mathrm{ft}$.), where it makes its second angle to the north, has been replaced with 30 inch diameter pipe. Facilities within $500 \mathrm{ft}$. according to these drawings are:

- Purex Railroad tracks - same as in Section 3.1 (drawing H-2-55501, including sheets 4 and 5. .) 
- Interplant Transfer Encasement, LN 244-PAS-3" and LN 228-PSN-3" approximately $170 \mathrm{ft}$. north of the trench and running parallel to it for more than 1,136 ft. (drawing $\mathrm{H}-2-36642$ ).

- A two line encasement crosses the trench where it has been replaced with the 30 inch diameter pipe. The encasement leads to 244-AR Vault (drawing H-2-61970).

- $\quad 13.8 \mathrm{KV}$ primary electrical lines also cross the trench where it has been replaced with 30 inch pipe (drawing $\mathrm{H}-2-2467$, sheet 4).

- 216-A-9 waste crib - same as in Section 3.1. Two wells associated with this crib are also shown: Well 299-E24-5 is about $350 \mathrm{ft}$. from the trench and Well 299-E24-63 is about $310 \mathrm{ft}$ from the trench (drawing $\mathrm{H}-2-55579$ ).

- 216-A-40 diversion ditch. A corner of the 216-A-40 diversion ditch is about $85 \mathrm{ft}$. from the headwall that marked the original end of the powerhouse wastewater trench at its eastern end (drawing H-2-63084). The 216-A-40 diversion ditch is approximately 460 feet from the current end point of the Powerhouse Trench.

- C Plant facilities as listed in Section 3.1.

- Several additional pipelines (encasements, sanitary water, cooling water, raw water process piping, etc.) are located within $500 \mathrm{ft}$. of the trench at its eastern end.

\subsection{CONSTRUCTION OF THE NEW CROSS SITE TRANSFER LINE}

The replacement cross site transfer line being installed by Project $W-058$ is located north of the wastewater trench and parallel to it, at a distance greater than $170 \mathrm{ft}$. north $(\mathrm{H}-2-822225,6,7)$. Project $\mathrm{W}-058$ drawings indicate that Project $\mathrm{W}-049 \mathrm{H}$ also installed piping in the vicinity. Project $\mathrm{W}-\mathrm{O} 49 \mathrm{H}$ installed the 200 Area TEDF transfer line (drawing H-2-140323). Both of these sets of pipelines are expected to be active.

\subsection{REPLACEMENT OF THE EAST END OF THE POWERHOUSE WASTEWATER TRENCH WITH PIPING}

In 1996, 360-400 feet of the eastern end of the wastewater trench was replaced with new 24 inch pipe and buried. This eliminated the part of the trench that ran northeast at the eastern end, which was closest to the 216-A-40 diversion ditch and area piping. The purpose for modifying the wastewater trench was to address radioactive contamination brought to the trench from other locations by animals. The buried area is posted for underground contamination. 


\subsection{OTHER MODIFICATIONS}

- The last 18 years, the trench has been scraped three times to remove weeds.

- Project B-604 is installing a new water storage tank that has an overflow to the 282-E Reservoir.

\subsection{CURRENT WASTEWATER TRENCH CONFIGURATION AND OPERATION}

The current configuration of the trench is now approximately $1860 \mathrm{ft}$. long, and 6 to $8 \mathrm{ft}$. wide at the base. The trench and surrounding facilities are shown in Figure 3-1. Assuming the water covers the bottom of the trench, (observation shows the water to be ordinarily shallow) the area available for percolation is 11,160 to 14,880 square feet. Based on the design percolation rate of the 200 Area TEDF, which is $10 \mathrm{gal} / \mathrm{ft}^{2}$ per day, water seeping from the trench could be as much as 111,600 to 148,800 gallons per day ( 78 to 103 gallons/minute). The actual rate of water percolation from the trench is likely to be smaller, due to soil surface blinding from suspended solids deposition and vegetation. Visual observation of the flow entering and exiting the trench did not reveal any discernable difference, however, measurements have not been made.

If the percolation were to be at the maximum rate, it would represent up to $69 \mathrm{vol} \%$ of the current average flow rate of water discharged from the powerplant and water treatment facilities. This would also represent only a small portion of the peak flow rate, which is 4,000 gallons/minute from filter backwash activities, or the potential 7,000 gallons/minute from overflow of the 282-E Reservoir. In order to verify the percolation rate, flow rates at the beginning and the end of the trench would have to be measured and compared.

\subsection{EFFECT OF TRENCH OPERATION ON HANFORD SITE GROUNDWATER}

Two reports address groundwater monitoring at the Hanford Site. The Annual Report for RCRA Groundwater Monitoring Projects at Hanford Site Facilities for 1995 (DOE 1996) shows that none of the RCRA monitored sites are near to the 284-E Powerhouse Trench. This document shows the water table in the $200 E$ Area to be nearly flat at about 122.25 to 122.5 meters $(401 \mathrm{ft}$. to $402 \mathrm{ft}$.) below the surface, with the greatest influence being exerted by $B$ Pond. No mounding of water is shown in the area beneath the trench.

Hanford Site Groundwater Monitoring for 1995 (PNNL 1996), shows the same depth to groundwater in the 200 East Area, and does not show the Powerhouse Trench to be in the vicinity of major sources of contaminants, including nitrate, iodine, or tritium. This report indicates that the water table beneath the 200 East Area has been dropping, due to reductions in discharge of wastewater. It also does not indicate mounding of water beneath the trench. 


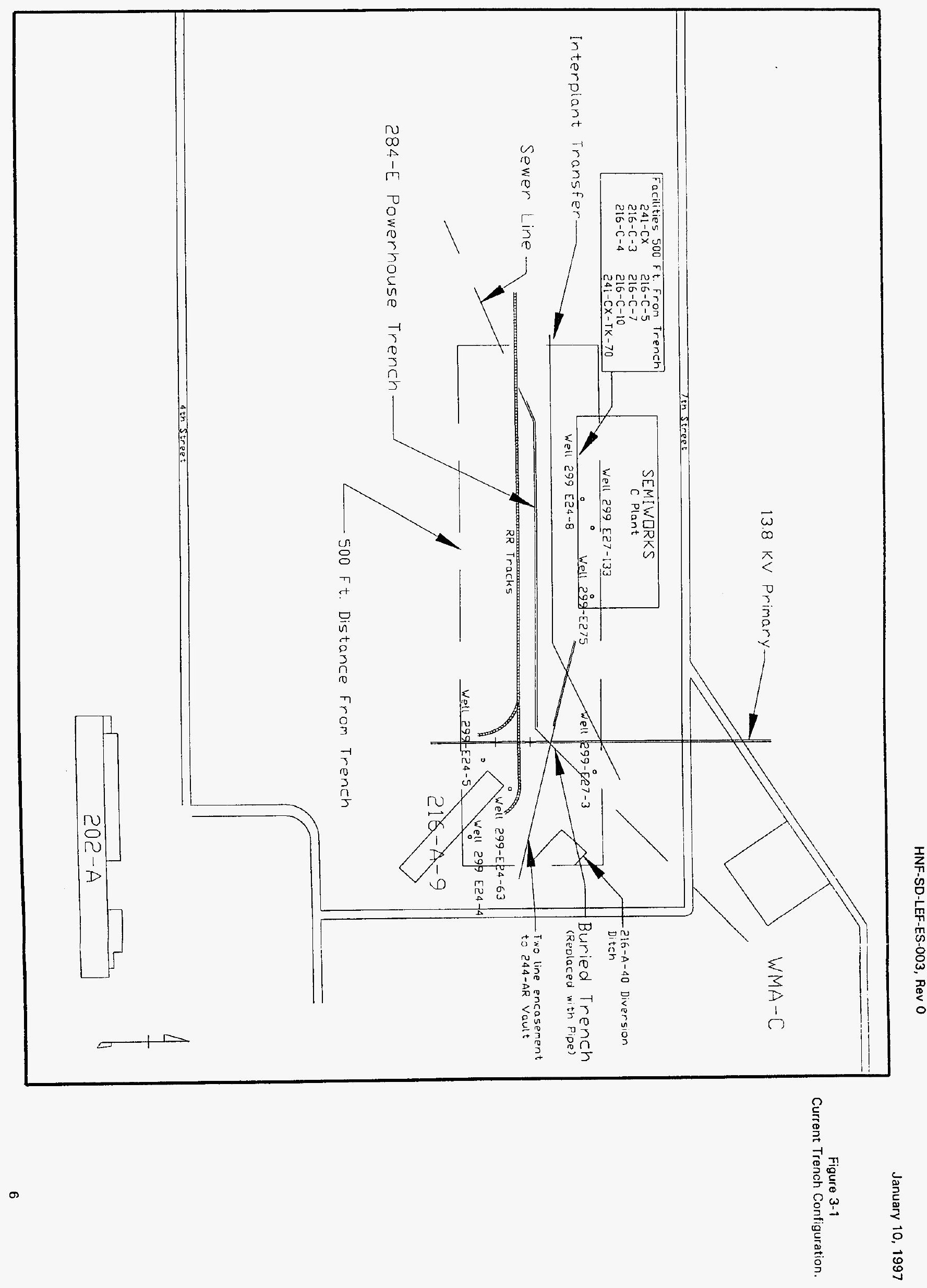


Figure 3-1 shows monitoring wells in the vicinity of the 284-E Powerhouse Trench. They are: Well 299 E-24-4, Well 299 E-24-5, Well 299 E-24-8, Well 299 E-24-63, Well 299 E-27-3, Well 299 E-27-5, and Well 299 E-27-133.

\subsection{POWERHOUSE TRENCH MANAGEMENT OPTIONS}

Options supporting current operations include the following:

1. No modification to the trench.

2. Replacement of the trench with a pipeline and engineered solution to resolve surge capacity and suspended solids removal issues prior to discharge to the 200 Area TEDF.

The trench cannot be solely replaced with a pipeline under current operations. A pipeline would not prevent discharge of suspended solids to the 200 Area TEDF, which was not designed to accept solids. It would also not provide surge capacity to retain wastewater during high flow rate periods.

\subsection{EVALUATION OF OPTIONS}

Table 6-1 shows a comparison of trench management options to criteria.

\subsection{ACCEPTANCE AT TEDF}

The acceptability of the effluent for disposal in the 200 Area TEDF is noted, because only streams without sludge can be disposed there.

\subsection{MOBILIZATION OF CONTAMINANTS FROM NEARBY FACILITIES}

The potential for each option to mobilize existing contamination is also addressed in the criteria. For the no change option, mobilization of existing contamination is unlikely for two reasons. (1) The major facilities in the area of the Powerhouse Wastewater Trench are all inactive and are at a distance from the trench; and (2) no significant water mound has been noted beneath the trench. Adjacent facilities are: 
- C Plant (Semiworks), which conducted pilot plant work and separated fission products. It has associated cribs and is $\mathbf{3 8 8} \mathrm{ft}$. north of the wastewater trench. The Semiworks Facilities include:

216-C-3 Start Date: January 1953

End Date: March 1954

Unit Status: Inactive

216-C-4

Start Date: July 1955

End Date: May 1965

Unit Status: Inactive

216-C-5

Start Date: March 1955

End Date: June 1955

Unit Status: Inactive

216-C-7

Start Date: May 1961

End Date: 1969

Unit Status: Inactive

216-C-10

Start Date: November 1964

End Date: October 1969

Unit Status: Inactive, Stabilized 1992

241-CX Crib

Start Date: September 1955

End Date: September 1964

Unit Status: Inactive

241-CX-TK-70

Start Date: 1952

End Date: 1957

Unit Status: Inactive

- 241-A-9 Crib

Start Date: March 1956

End Date: August 1969

Unit Status: Inactive

- 216-A-40

Diversion Trench

Start Date: January 1968

End Date: May 1979

Unit Status: Inactive, stabilized 1994

Operating/stabilization dates for cribs and trenches are per 200 East and North Areas Radioactive Liquid Waste Disposal Sites (ARH 1970) and Hanford Site Waste Management Units Report, Overview of the Waste Information Data System (DOE 1996a).

Various pipelines are also in the vicinity of the Powerhouse Wastewater Trench, however, active process piping carrying contaminated wastes is encased or pipe-in-pipe construction and is instrumented for leak detection.

Continued operation of the trench is not likely to mobilize existing plumes because of its distance from other facilities and the lack of a water mound beneath it. No evidence of water mounding beneath the trench is apparent, based on examination of wells in the Area. Wells are shown in Figure 3-1. 
Construction activities to install piping and surge/settling capacity options could also contact existing contamination, although this is expected to be unlikely, due to the distance of the site from active facilities.

Table 6-1. Comparison of Options to Criteria.

\begin{tabular}{|c|c|c|}
\hline $\begin{array}{c}\text { Discharge acceptable to } 200 \text { Area } \\
\text { TEDF }\end{array}$ & $\begin{array}{c}\text { Option 1 No } \\
\text { Change }\end{array}$ & $\begin{array}{c}\text { Option 2 Pipeline \& Engineered } \\
\text { Surge/Settling Solution }\end{array}$ \\
\hline $\begin{array}{c}\text { Mobilizes existing contamination from } \\
\text { other facilities }\end{array}$ & no & yes \\
\hline $\begin{array}{c}\text { Requires attention to periodic } \\
\text { contamination } \\
\text { from animals } \\
\text { Annual Cost }\end{array}$ & $\begin{array}{c}\text { Estimate } \\
\$ 30,000 \\
\text { over } 5 \text { years }\end{array}$ & 0 \\
\hline Estimated Capital Cost & 0 & $\begin{array}{c}\$ 800,000 \text { to } \\
\$ 1,100,000^{(2)}\end{array}$ \\
\hline Total Costs & $\$ 30,000$ & $\begin{array}{l}\$ 800,000 \text { to } \\
\$ 1,100,000\end{array}$ \\
\hline
\end{tabular}

Notes:

(1) Estimate provided by 0 . Rasmussen, based on past experience.

(2) Least Cost Estimate from 200 Area Effluent Trench Alternatives Analysis (ICF-KH 1996).

\subsection{PERIODIC CONTAMINATION CONTROL}

The water in the powerplant wastewater trench has supported the growth of vegetation and occasionally attracts animals. In the past there has been evidence at the easterly end of the trench (which has been buried) where radioactive contamination has been detected. Animals are suspected to have contacted radioactive contamination and transported it to the trench. They are the only known source of radioactive contamination. Continued operation of the trench may require occasional attention to control the spread of contamination. However, costs should not be greater than during past operations, particularly as site remediation activities continue to reduce the number of locations vulnerable to animal intrusion. If the wastewater trench is replaced with pipelines and engineered facilities, the extent of this problem would be greatly reduced or eliminated.

A 1994 action that included removing contamination from the area of the trench cost about $\$ 30,000$. This work is done only on an as-needed basis, so the cost is shown as once/5 years. 


\subsection{CAPITAL COSTS FOR CONSTRUCTION}

Continued operation of the Powerhouse Wastewater Trench would not involve capital costs. Construction of engineered alternatives for replacement pipelines or surge/settling basins would involve costs as developed in the 200 Area Effluent Trench Alternatives Analysis (ICF KH 1996).

\subsection{CONCLUSIONS AND RECOMMENDATIONS}

Based on examination of existing data, continued use of the 284-E Powerhouse Trench as a transport conduit does not appear to impact the groundwater or cause the migration of existing contamination into or through the groundwater for any of the scenarios. This is based on groundwater monitoring, distance to adjacent facilities and the inactive status of adjacent facilities.

Should contamination control be identified as an ongoing issue, an engineered solution for solids removal and surge reduction issues along with a pipeline within the trench would be recommended.

The sum of capital and radiation control costs shows the least cost option to be no change to current trench operations.

\subsection{REFERENCES}

ARH 1970, 200 East and North Areas Radioactive Liquid Waste Disposal Sites, ARH-1562, L.L. Lundgren, Atlantic Richfield Hanford Company, Richland, Washington, January 1970.

DOE 1996, Annual Report for RCRA Groundwater Monitoring Projects at Hanford Site Facilities for 1995, DOE/RL-96-01, U.S. Department of Energy, Richland, Washington, February 1996.

DOE 1996a, Hanford Site Waste Management Units Report, Overview of the Waste Information Data System, DOE/RL-88-30, U.S. Department of Energy, Richland, Washington, May 1996.

DOE 1996b, 200 East Treated Effluent Disposal Facility (TEDF) Supplemental Permit Application, U.S. Department of Energy, Richland, Washington, October 1996.

ERDA 1538, Final Environmental Statement, Hanford Waste Management Operations, U.S. Energy Research and Development Administration, Richland, Washington, December 1975. 
ICF KH 1996, 200 Area Effluent Trench Alternatives Analysis, KH-SD-LL-RPT-002, ICF Kaiser Hanford Company, Richland, Washington, September 1996.

PNNL 1996, Hanford Site Groundwater Monitoring for 1995, PNNL-11141, Pacific Northwest National Laboratory, Richland, Washington, August 1996.

WHC 1992, Phase /I Liquid Effluent Program (Project W-252) Wastewater Engineering Report and BAT/AKART Studies, WHC-SD-W252-ER-001, Rev.0, Westinghouse Hanford Company, Richland, Washington, September 1992.

Drawings:

M-2904-E, Sheets 24 and 27, Hanford Site Maps

H-2-44501, Sheets 70, 71, 72, 81, 82, and 83, Area Map 200 East, "A" Plant Facilities 


\section{DISTRIBUT ION}

$\begin{array}{ll}\text { AF Crane } & S 6-71 \\ \text { PJ Davis-Vedder } & H 6-22 \\ \text { JL Day } & S 2-66 \\ \text { DL Flyckt } & S 6-71 \\ \text { JM Hache } & S 2-12 \\ \text { RD Haggard } & \mathrm{H6}-25 \\ \text { DR Herman } & \mathrm{S}-12 \\ \text { DW Lindsey } & S 6-71 \\ \text { JJ Luke } & \mathrm{H6}-25 \\ \text { RJ Nick7as } & \mathrm{S6-72} \\ \text { RE Piippo } & \mathrm{L} 0-16 \\ \text { OR Rasmussen } & \mathrm{R} 1-51 \\ \text { NJ Sullivan } & \mathrm{S6-72} \\ \text { TL Sweet } & \mathrm{S} 2-12 \\ \text { BH Von Bargen } & \mathrm{S6}-72 \\ & \\ \text { Regulatory File } & \mathrm{S} 6-72 \\ \text { Central Files } & \mathrm{A} 3-88\end{array}$

